\title{
PENGEMBANGAN LONGEST PATH ALGORITHM (LPA) DALAM RANGKA PENCARIAN LINTASAN TERPANJANG PADA GRAF BERSAMBUNG BERARAH BERUNTAI
}

\author{
Oliver Samuel Simanjuntak \\ Prodi Teknik Informatika UPN "Veteran" Yogyakarta \\ Jl. Babarsari 2 Tambakbayan 55281 Telp (0274) 485323 \\ email: oliver.simanjuntak@upnyk.ac.id
}

\begin{abstract}
The longest distance in a graph that has a number of vertices, arcs and small strands easily done manually. However, if the graph has a number of vertices, arcs and strands of many, the determination of the distance and the longest path will be difficult. Research has developed Longest Path Algorithm (LPA) in order to search for the longest distance and trajectory continued trending stranded on a graph. LPA enables application development and search distance of the longest path in the graph continued trending quickly and accurately. LPA in the development of a solution to help solve the problem of finding the longest path in a directed graph stranded concatenated.

Keywords: LPA, the longest distance, continued trending graph stranded.

Pencarian jarak dan lintasan terpanjang pada graf yang memiliki jumlah verteks, arc dan untai yang kecil mudah dilakukan secara manual. Namun bila graf tersebut memiliki jumlah verteks, arc dan untai banyak, penentuan jarak dan lintasan terpanjang akan menjadi sukar. Penelitian berhasil mengembangkan Longest Path Algorithm (LPA) dalam rangka pencarian jarak dan lintasan terpanjang pada graf bersambung berarah beruntai. Aplikasi pengembangan LPA memampukan pencarian jarak dan lintasan terpanjang pada graf bersambung berarah secara cepat dan tepat. Pengembangan LPA menjadi solusi dalam membantu memecahkan masalah pencarian lintasan terpanjang pada sebuah graf bersambung berarah beruntai.

Kata-kunci: LPA, lintasan terpanjang, graf bersambung berarah beruntai
\end{abstract}

\section{PENDAHULUAN}

Graf direpresentasikan sebagai suatu pekerjaan yang berdasar pada kumpulan obyek dan sub-sub aktifitasnya. Aktifitas dilakukan secara simultan atau setelah suatu aktifitas lain selesai. Dalam graf, kumpulan obyek dan sub-sub aktifitasnya disebut verteks dan arc. Pengaturan seluruh verteks dan arc agar pekerjaan dapat diselesaikan dengan waktu minimun disebut Longest path problem. Longest path problem menentukan seluruh pekerjaan dapat diselesaikan dengan perancangan waktu minimum.

Longest Path Algorithm (LPA) merupakan metode untuk pencarian lintasan terpanjang pada sebuah graf bersambung berarah. Untuk pencarian lintasan terpanjang dari sebuah graf bersambung dan berarah, dapat digunakan perhitungan cara manual atau dengan melalui komputer. Pencarian lintasan terpanjang pada graf bersambung berarah yang memiliki jumlah verteks dan arc sedikit melalui cara manual akan mudah dilakukan pencari. Namun bila graf tersebut memiliki jumlah verteks dan arc yang besar, pencarian lintasannya akan menjadi sukar. Pencarian lintasan secara mudah dan akurat dapat dilakukan dengan bantuan komputer. Dalam pencarian lintasan terpendek dan terpanjang, komputer mengandalkan logika yang kita tuangkan dalam sebuah algoritma pemrograman pencarian lintasannya.

Masalah yang diangkat dari penelitian ini adalah pencarian lintasan terpanjang pada sebuah graf bersambung berarah beruntai. Untuk itu, akan dibuat sebuah pengembangan metode LPA dalam rangka pencarian lintasan beruntai. Aplikasi pengembangan LPA mampu mencari jarak dan lintasan terpanjang pada graf bersambung berarah beruntai. 


\section{TINJAUAN PUSTAKA}

\subsection{Graf}

Graf didefinisikan sebagai graf $G=(V, E)$ yang terdiri dari suatu himpunan objek $V=\left(v_{1}, v_{2}, \ldots v_{n}\right)$ yang disebut verteks dan himpunan lain $E=\left(e_{1}, e_{2}, \ldots e_{n}\right)$ yang elemen-elemennya disebut edge, sedemikian sehingga tiap-tiap edge $e_{n}$ diidentifikasikan dengan pasangan verteks tak urut (Even,1979). Menurut Wilson (1990), sebuah edge biasanya akan menghubungkan dua buah verteks yang berlainan, namun akan ada kasus dimana edge menghubungkan 1 verteks yang sama $\left(v_{i}, v_{i}\right)$.

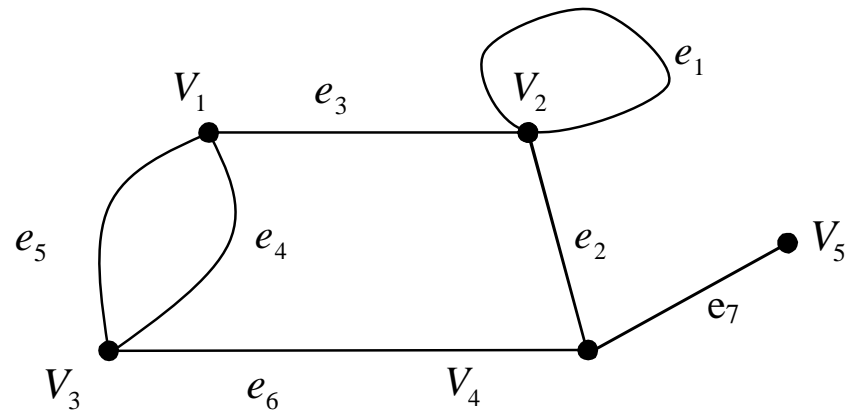

Gambar 1. Graf dengan 5 Verteks dan 7 Edge

\subsubsection{Lintasan dan Untai}

Lintasan didefinisikan sebagai deret bergantian terhingga dari verteks dan edge. Lintasan dimulai dan diakhiri dengan verteks, sehingga tiap-tiap edge berpengaruh dengan verteks yang mendahului dan mengikutinya. Pada gambar 2 , misalkan $V_{1} a V_{2} b V_{3} c V_{3} d V_{4}$ e $V_{2} f V_{5}$ adalah lintasan yang ditunjukkan dengan garis tebal. Lintasan tertutup dimana tak ada verteks kecuali verteks awal dan akhir muncul lebih dari sekali disebut untai. Untai ditunjukkan pada gambar 2, yaitu: $V_{2} b V_{3} d V_{4}$ e $V_{2}$. Untai juga disebut untai, elementary untai, circular path dan polygon (Gross, 1998).

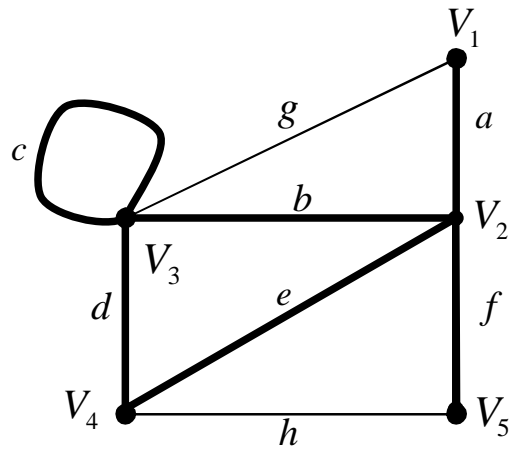

Gambar 2. Sebuah Lintasan

\subsubsection{Graf Berarah}

Graf berarah (directed graf atau singkatnya digraf) $G$ berisi himpunan verteks-verteks $V=\left\{v_{1}, v_{2}, \ldots\right\}$ dan daftar pasangan berurut $A=\left\{a_{1}, a_{2}, \ldots\right\}$ dari elemen tersebut yang disebut dengan arc (Wilson, 1990). Jika $v_{\mathrm{i}}$ dan $\mathrm{v}_{\mathrm{j}}$ adalah verteks dari $V$, maka ah(vi,vj) adalah arc $h$ dengan bentuk $\mathrm{v}_{\mathrm{i}} \mathrm{v}_{\mathrm{j}}$ dikatakan berarah dari $\mathrm{v}_{\mathrm{i}}$ ke $\mathrm{v}_{\mathrm{j}}$ atau menggabungkan $\mathrm{v}_{\mathrm{i}}$ ke $\mathrm{v}_{\mathrm{j}}$.

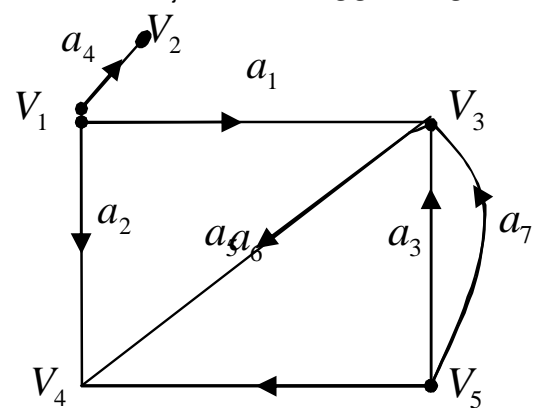

Gambar 3. Graf Berarah dengan 5 Verteks dan 7 Arc 


\subsection{Metode Pencarian Lintasan Terpanjang}

\subsubsection{Algoritma Lintasan Terpanjang}

Metode pencarian lintasan terpanjang dengan LPA, jarak terpanjang dari verteks awal ke verteks akhir dapat ditemukan dengan algoritma (Wilson, 1990):

- Langkah pertama: Beri verteks awal dengan potensial 0 , kemudian labelkan tiap verteks $v$ yang dicapai hanya dari verteks awal dengan jarak dari verteks awal ke $v$ dan buat itu sebagai label potensial.

- Langkah umum:

- Pertimbangkan semua verteks yang dapat dicapai hanya dari verteks yang bertanda potensial.

- Untuk tiap verteks $w$, pandang tiap arc $v w$ dalam $w$ dan labelkan $w$ dengan label: (potensial $v$ ) + (jarak dari $v$ ke $w$ ) jika $w$ adalah label terbesar

- Bila semua arc $v w$ telah dipikirkan, buat label $w$ sebagai potensial

- Ulangi langkah umum dengan potensial yang baru

- STOP: Bila verteks akhir telah diberi tanda potensial. Ini merupakan jarak terpanjang verteks awal ke verteks akhir.

- Rute Lintasan Terpanjang: Mulai menghitung terbalik dari verteks akhir ke verteks awal dan verteks $v w$ dimasukkan bila: (potensial $w)-($ potensial $v)=($ jarak dari $v$ ke $w)$

\section{PERANCANGAN SISTEM}

Sebuah graf bersambung berarah beruntai minimal harus memiliki dua buah verteks dan sebuah arc yang menghubungkannya. Sebuah verteks memiliki data-data seperti koordinat $x$ dan koordinat y serta nama yang perlu disimpan. Penyimpanan verteks pada sistem dapat menggunakan penyimpanan larik (array). Penyimpanan arc hampir sama dengan verteks, sama-sama menggunakan larik (array). Data-data arc yang perlu disimpan adalah verteks awal, verteks akhir, bobot dan nama arc yang disimpan. Pencarian lintasan terpanjang pada sebuah graf memerlukan data-data. Lintasan terpanjang pada graf memiliki data-data seperti besar potensial, besar label, keterangan dan nama verteks. Penyimpanan data-data lintasan terpanjang pada sistem menggunakan larik (array).

\subsection{Algoritma Pemrograman}

Langkah pertama yang harus dilakukan adalah memberikan potensial verteks awal $=0$. Masing-masing verteks yang terhubung hanya dengan verteks awal graf diberikan label dan jadikan verteks potensial. Langkah umum yang harus dilakukan adalah memberikan label pada verteks yang terhubung hanya dengan verteks potensial. Langkah umum dilakukan selama verteks akhir graf bukan verteks potensial. Verteks potensial merupakan verteks terpilih dengan nilai label terbesar. Gambar 4 merupakan gambar diagram alir algoritma pencarian lintasan terpanjang pada graf bersambung menggunakan modifikasi metode LPA. 


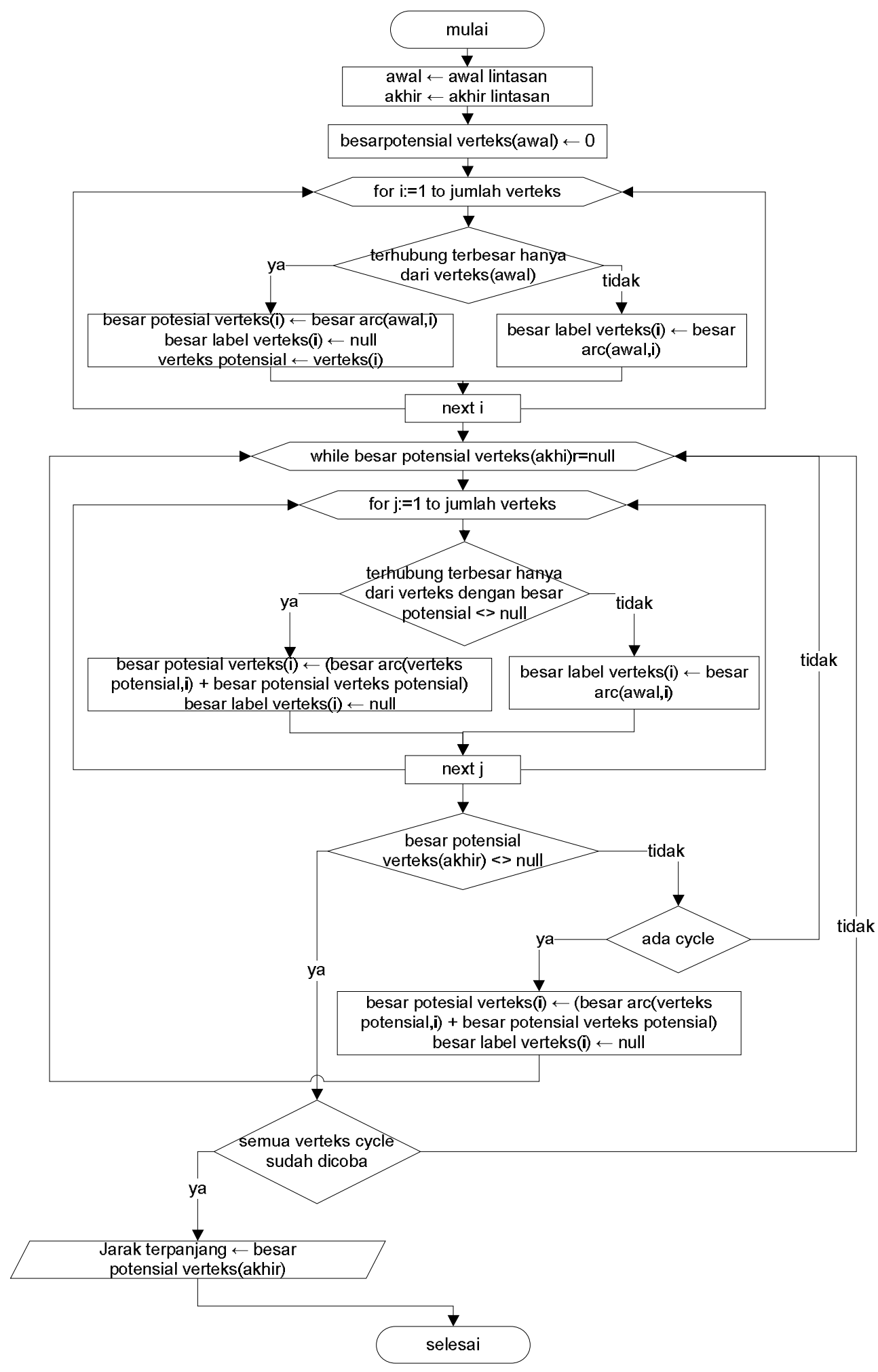

Gambar 4. Gambar Diagram Alir Pencarian Lintasan Terpanjang

\subsection{Perancangan Antarmuka}

Secara umum, kebutuhan terhadap antarmuka yang akan dibuat sebaiknya harus bersifat user friendly (ramah terhadap pengguna / mudah pengoperasiannya) dan interaktif artinya user sebagai pengguna terakhir dapat menggunakan sistem yang dibuat semudah mungkin sehingga user mengoperasikannya dengan mudah. Dengan mempertimbangkan berbagai aspek, maka dibuatlah perancangan antarmuka tampak seperti pada gambar 5 . 


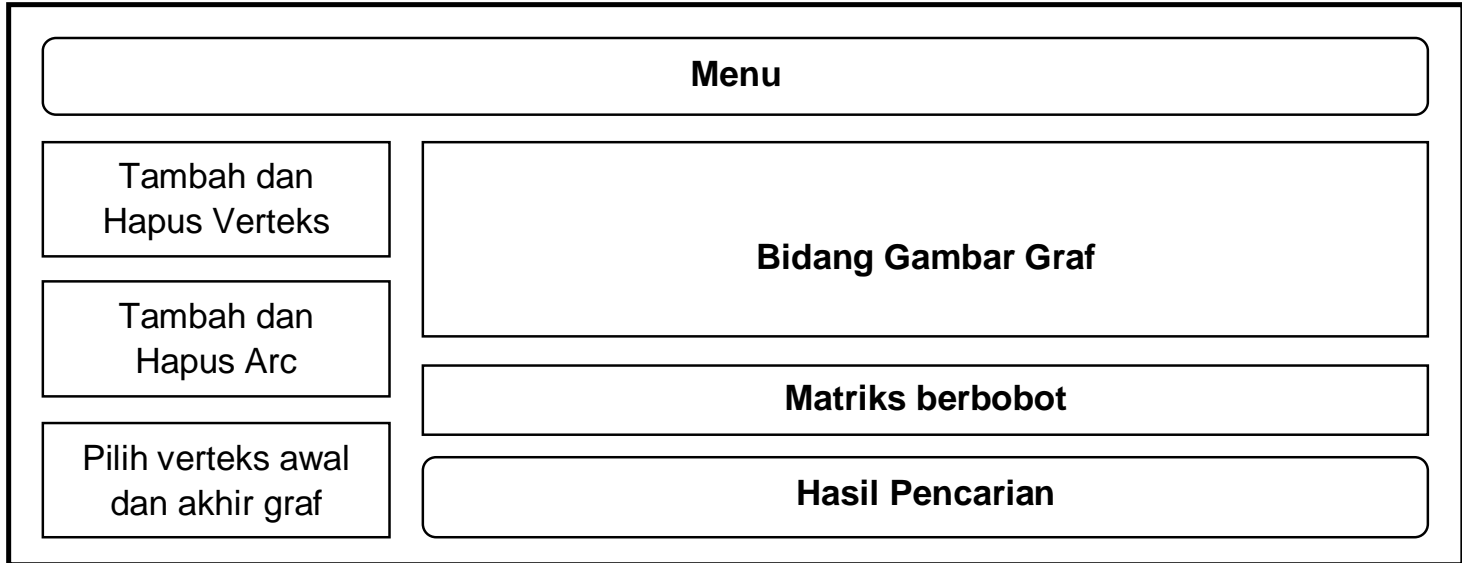

Keterangan gambar :

Gambar 5. Perancangan Antarmuka

- Menu

- Berkas, yang terdiri dari: buka, baru, simpan dan keluar

Proses Pengembangan Pencarian Lintasan Terpanjang.

Tambah dan Hapus Verteks. Terdiri dari sejumlah komponen untuk menambah dan menghapus verteks.

Tambah dan Hapus Arc. Terdiri dari sejumlah komponen untuk menambah dan menghapus arc.

Pilih Verteks Awal dan Akhir Graf. Terdiri dari sejumlah komponen untuk memilih verteks awal dan verteks akhir lintasan pada graf.

Bidang Gambar Graf. Daerah ini digunakan untuk membuat gambar graf secara visual dan manual serta menampilkan gambar graf yang sudah disimpan dan terpanjang.

Hasil Pencarian. Menampilkan jarak dan lintasan terpanjang atau terpendek

\section{IMPLEMENTASI DAN ANALISIS SISTEM}

\section{1 implementasi Sistem}

Bila aplikasi dijalankan, maka akan terlihat tampilan awal sistem seperti yang terlihat pada Gambar 6.

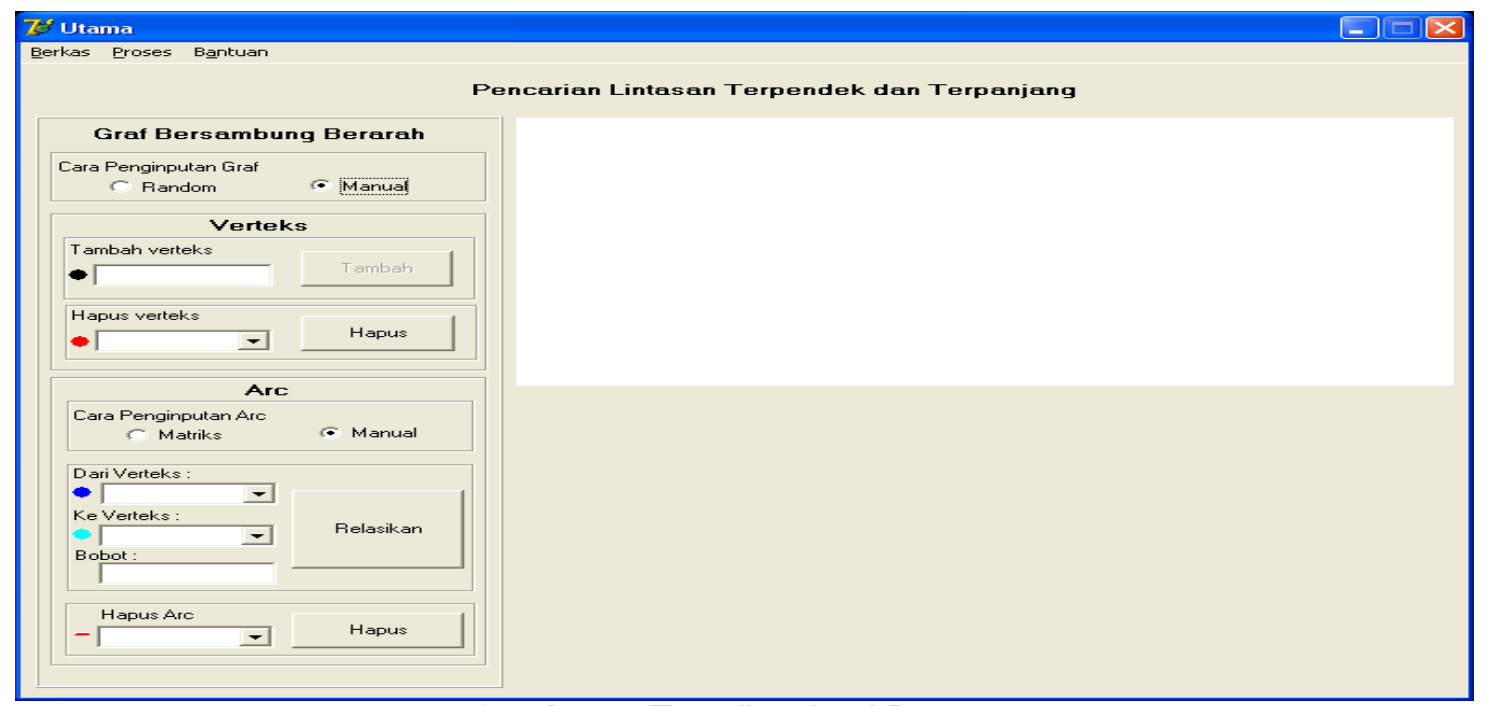

Gambar 6. Tampilan Awal Program 
Proses selanjutnya adalah penginputan graf. Untuk menginput graf maka harus ditentukan terlebih dulu verteks dan arc. Aplikasi menyimpan data verteks dan arc. Tampilannya dapat dilihat pada gambar 7 .

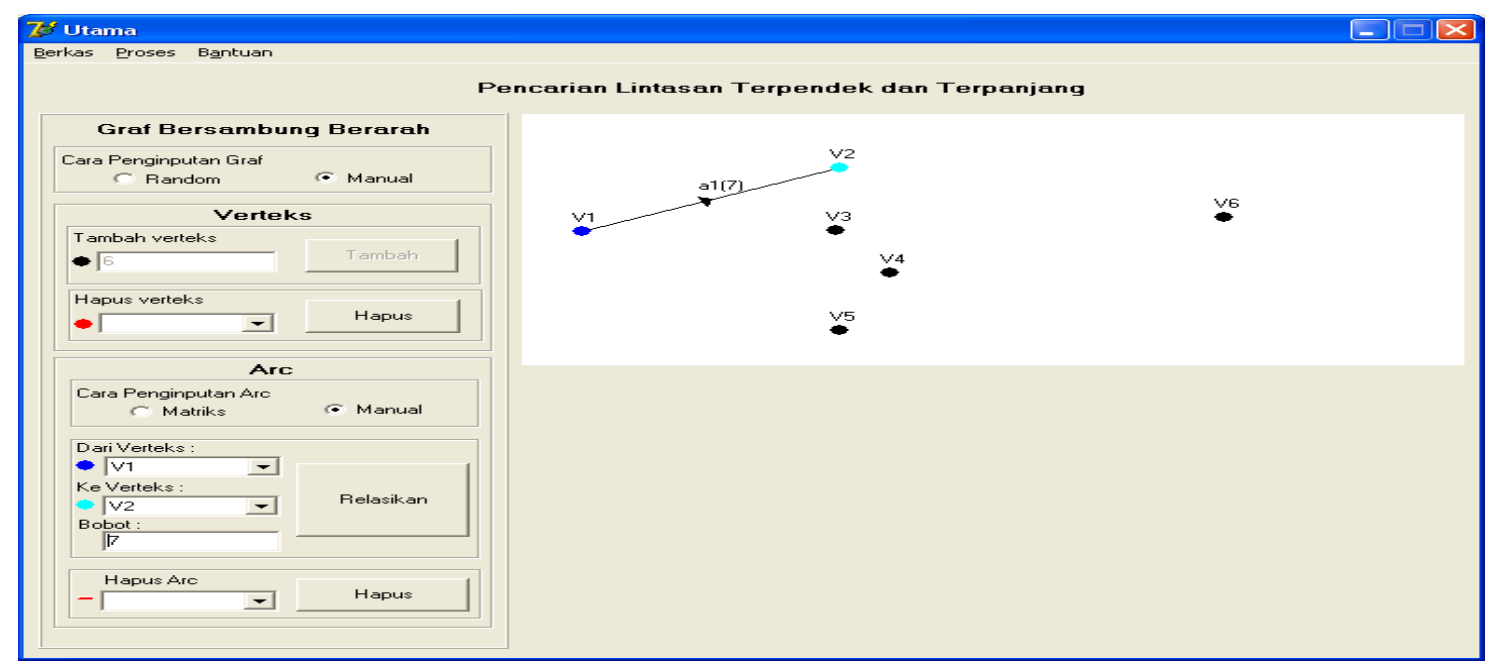

Gambar 7. Input Graf

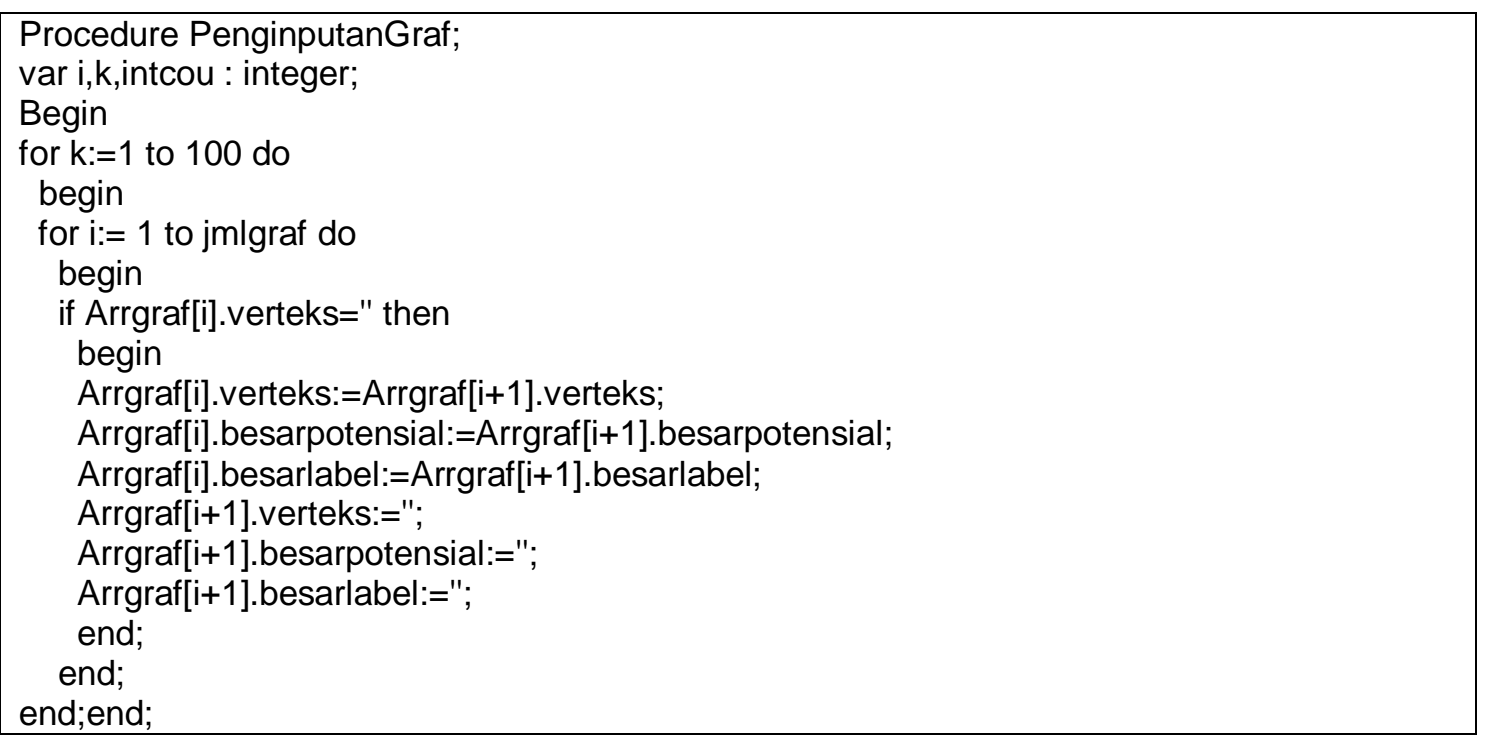

Modul 1. Prosedur Input Graf

Proses setelah input graf adalah pencarian lintasan terpanjang. Berdasar penentuan verteks awal dan akhir, aplikasi mencari lintasan terpanjang dari verteks awal ke akhir. Tampilannya dapat dilihat pada gambar 8 . 


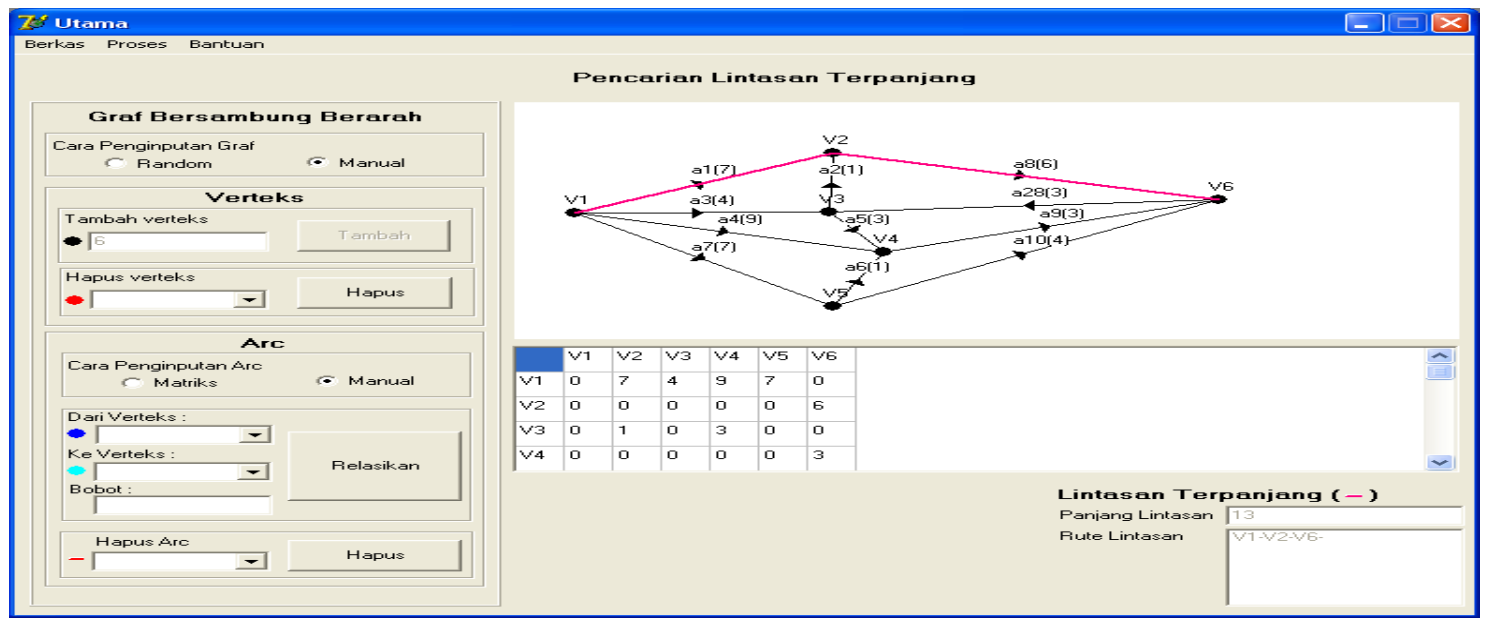

Gambar 8. Pencarian Lintasan Terpanjang

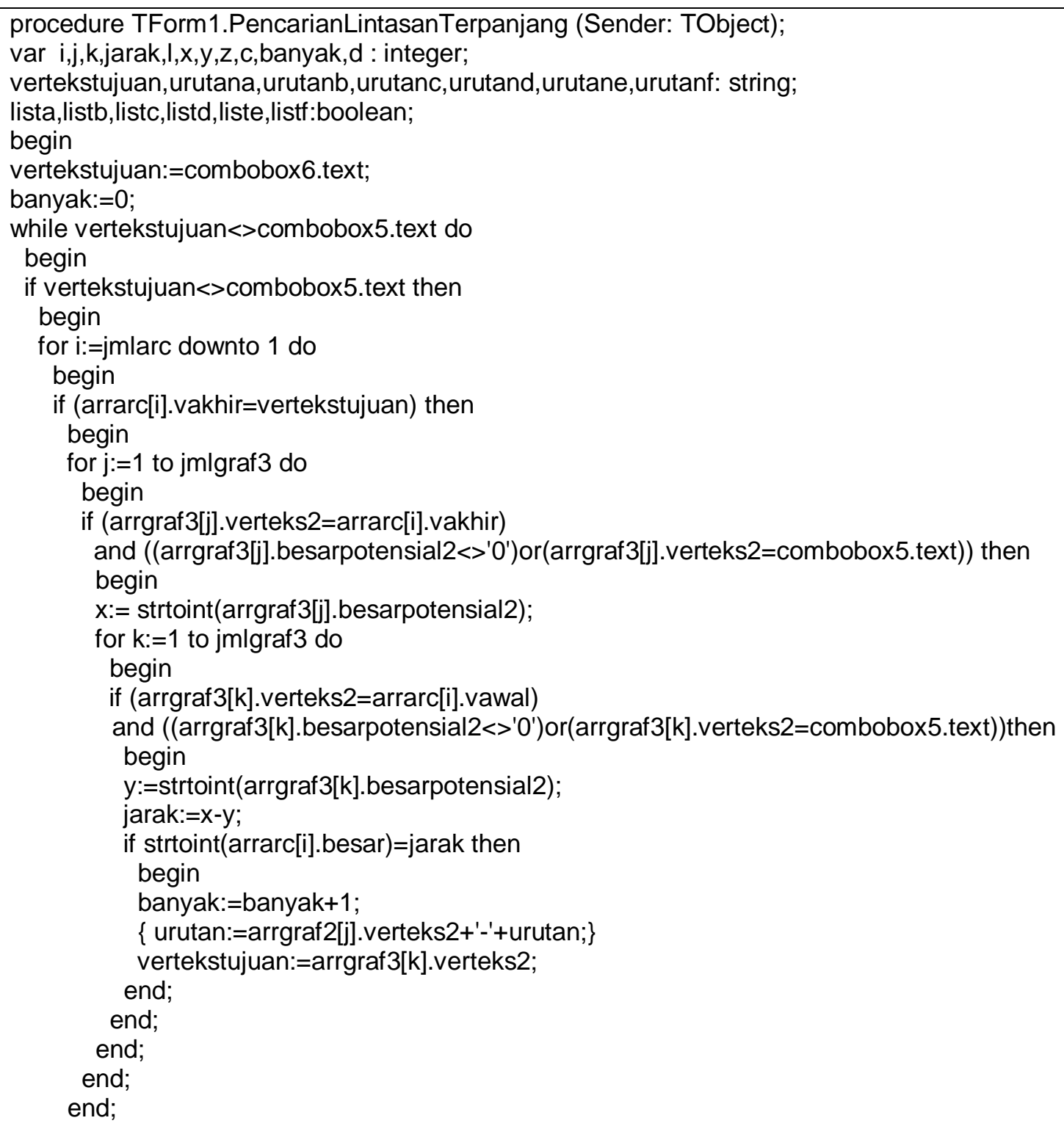

Modul 2. Prosedur Pencarian Lintasan Terpanjang 


\subsection{Analisis Sistem}

Pencarian lintasan terpanjang menggunakan pengembangan metode LPA. Proses ini akan menampilkan sajian matiks berbobot dan menampilkan hasil pencarian berupa lintasan terpanjang pada graf. Gambar 9 merupakan gambar tampilan proses pencarian lintasan terpanjang menggunakan pengembangan metode LPA.

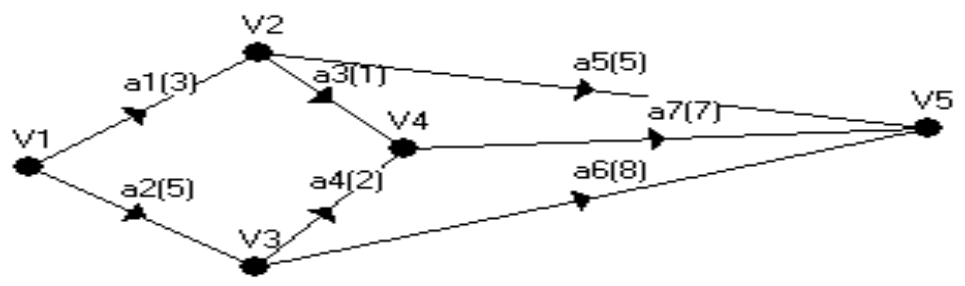

Gambar 9. Graf Bersambung Berarah Tanpa Untai

Dari gambar 9, metode pencarian lintasan terpanjang dari verteks V1 ke verteks V 5 dengan beberapa iterasi dapat ditabulasikan sama seperti pada pencarian lintasan terpanjang menggunakan pengembangan metode LPA. Metode LPA dikembangkan untuk memecahkan permasalahan metode LPA dalam pencarian lintasan terpanjang pada graf bersambung berarah beruntai. Metode pencarian lintasan terpanjang dari verteks V1 ke verteks V5 dengan beberapa iterasi dapat ditabulasikan sebagai berikut:

- Iterasi 0

Tabel 1. Data Graf Iterasi 0

\begin{tabular}{|c|c|c|c|c|c|}
\hline Verteks2 & Besar Potensial2 & Besar Label2 & Keterangan2 & Keterangan3 & Keterangan untai \\
\hline V1 & 0 & - & 3 & 0 & - \\
\hline V2 & - & 2 & 1 & 2 & - \\
\hline V3 & - & 3 & 2 & 2 & - \\
\hline V4 & - & 4 & 1 & 2 & - \\
\hline V5 & - & - & 0 & 1 & - \\
\hline
\end{tabular}

Nilai Keterangan2 pada verteks $v$ adalah jumlah verteks yang dituju verteks $v$. Nilai Keterangan3 pada verteks $v$ adalah jumlah verteks yang menuju verteks $v$. Nilai keterangan untai pada verteks $v$ adalah level untai yang menentukan nilai besar potensial verteks $v$. Beri potensial verteks $v=0$, jika keterangan2 verteks $v=0$ dan verteks $v$ bukan verteks akhir lintasan. Beri potensial verteks $v=0$, jika keterangan3 verteks $v=0$ dan verteks $v$ bukan verteks awal lintasan. Beri potensial verteks awal lintasan $=0(\mathrm{~V} 1=0)$. Labelkan dengan nilai yang terbesar tiap verteks $\mathrm{v}$ yang dicapai dari verteks $\mathrm{V} 1$ dengan jarak dari verteks $\mathrm{V} 1$ ke verteks $\vee$ (besar label V2 $=3$, besar label V3 $=3$, besar label V4 $=4$ ). Besar potensial verteks $\mathrm{V}$ = besar label verteks $\mathrm{v}$, bila tiap verteks $\mathrm{v}$ dicapai hanya dari verteks potensial (tidak ada verteks potensial baru).

- Iterasi 1

Tabel 2. Data Graf Iterasi 1

\begin{tabular}{|c|c|c|c|c|c|}
\hline Verteks2 & Besar Potensial2 & Besar Label2 & Keterangan2 & Keterangan3 & Keterangan untai \\
\hline V1 & 0 & - & 3 & 0 & - \\
\hline V2 & - & 2 & 1 & 2 & - \\
\hline V3 & - & 3 & 2 & 2 & - \\
\hline V4 & - & 4 & 1 & 2 & - \\
\hline V5 & - & - & 0 & 1 & - \\
\hline
\end{tabular}

Labelkan dengan nilai yang terkecil tiap verteks $v$ yang dicapai hanya dari verteks $\mathrm{V} 1$ dengan jarak dari verteks $\mathrm{V} 1$ ke verteks $\mathrm{v}$. Besar potensial verteks $\mathrm{v}=$ besar label verteks $\mathrm{v}$, bila tiap verteks $v$ dicapai hanya dari verteks potensial (tidak ada verteks potensial baru). Tidak ada verteks potensial baru, graf bersambung berarah beruntai. Pencarian lintasan terpanjang menggunakan modifikasi metode LPA pada graf bersambung berarah beruntai menggunakan bantuan tabel data untai. 
Tabel 3. Data Untai Iterasi 1

\begin{tabular}{|c|c|c|c|}
\hline Verteks & Besar Potensial & Besar Label & Keterangan \\
\hline V2 & 2 & - & 0 \\
\hline V3 & 3 & - & 1 \\
\hline V4 & 4 & - & 1 \\
\hline
\end{tabular}

Verteks pada data untai adalah verteks untai yang dituju oleh verteks potensial. Keterangan menunjukkan level untai. Selanjutnya pilih verteks V2 pada data untai sebagai verteks potensial V2 dengan besar potensial 2 pada data graf. Keterangan data untai verteks V2 adalah 0.

- Iterasi 2

Tabel 4. Data Graf Iterasi 2

\begin{tabular}{|c|c|c|c|c|c|}
\hline Verteks2 & Besar Potensial2 & Besar Label2 & Keterangan2 & Keterangan3 & Keterangan untai \\
\hline V1 & 0 & - & 3 & 0 & - \\
\hline V2 & 2 & - & 1 & 2 & 1 \\
\hline
\end{tabular}

Tabel 4. Data Graf Iterasi 2 (Lanjutan)

\begin{tabular}{|c|c|c|c|c|c|}
\hline Verteks2 & Besar Potensial2 & Besar Label2 & Keterangan2 & Keterangan3 & Keterangan untai \\
\hline V3 & - & 5 & 2 & 2 & - \\
\hline V4 & - & 4 & 1 & 2 & - \\
\hline 5 & - & - & 0 & 1 & - \\
\hline
\end{tabular}

Labelkan dengan nilai yang terbesar tiap verteks $v$ yang dicapai hanya dari verteks $\mathrm{V} 1$ dan V2 dengan jarak dari verteks berpotensial ke verteks $v($ label verteks V3 $=5$ ). Besar potensial verteks $v$ = besar label verteks $v$, bila tiap verteks $v$ dicapai hanya dari verteks potensial (besar potensial verteks V3 $=5$ ). Keterangan untai verteks V3 adalah 1 (nilai keterangan untai verteks potensial terbesar).

- Iterasi 3

Tabel 5. Data Graf Iterasi 3

\begin{tabular}{|c|c|c|c|c|c|}
\hline Verteks2 & Besar Potensial2 & Besar Label2 & Keterangan2 & Keterangan3 & Keterangan untai \\
\hline V1 & 0 & - & 3 & 0 & - \\
\hline V2 & 2 & - & 1 & 2 & 1 \\
\hline V3 & 5 & - & 2 & 2 & 1 \\
\hline V4 & - & 7 & 1 & 2 & - \\
\hline V5 & - & 8 & 0 & 1 & - \\
\hline
\end{tabular}

Labelkan dengan nilai yang terbesar tiap verteks $v$ yang dicapai hanya dari verteks $V 1, \mathrm{~V} 2$ dan V3 dengan jarak dari verteks berpotensial ke verteks $\mathrm{V}$ (label verteks $\mathrm{V} 4=7$ dan V5 $=8$ ). Besar potensial verteks $v=$ besar label verteks $v$, bila tiap verteks $v$ dicapai hanya dari verteks potensial (besar potensial verteks V4 $=7$ dan V $5=8$ ). Keterangan untai verteks V4 dan V5 adalah 1 (nilai keterangan untai verteks potensial terbesar).

- Iterasi 4

Tabel 6. Data Graf Iterasi 4

\begin{tabular}{|c|c|c|c|c|c|}
\hline Verteks2 & Besar Potensial2 & Besar Label2 & Keterangan2 & Keterangan3 & Keterangan untai \\
\hline V1 & 0 & - & 3 & 0 & - \\
\hline V2 & 2 & - & 1 & 2 & 1 \\
\hline V3 & 5 & - & 2 & 2 & 1 \\
\hline V4 & 7 & - & 1 & 2 & 1 \\
\hline V5 & 8 & - & 0 & 1 & 1 \\
\hline
\end{tabular}

Verteks V5 telah diberi tanda potensial. Masukkan data graf dalam data tampung. Jarak terpanjang $=8$. 
Tabel 7. Data Tampung Iterasi 4

\begin{tabular}{|c|c|}
\hline Verteks & Besar Potensial \\
\hline V1 & 0 \\
\hline V2 & 2 \\
\hline V3 & 5 \\
\hline V4 & 7 \\
\hline V5 & 8 \\
\hline
\end{tabular}

Ada verteks data untai yang belum terpilih. Pencarian lintasan terpanjang menggunakan modifikasi metode LPA pada graf bersambung berarah dengan untai menggunakan tabel data untai.

Tabel 8. Data Untai Iterasi 4

\begin{tabular}{|c|c|c|c|}
\hline Verteks & Besar Potensial & Besar Label & Keterangan \\
\hline V2 & 2 & - & 0 \\
\hline V3 & 3 & - & 0 \\
\hline V4 & 4 & - & 1 \\
\hline
\end{tabular}

Pilih verteks dengan keterangan $\neq 0$ pada data untai sebagai verteks potensial. Verteks $V 3$ dengan keterangan 1 pada data untai dan besar potensial 3 pada data graf. Besar potensial verteks data graf dengan keterangan untai 1 , jadikan null. Keterangan data untai verteks V3 adalah 0 .

Verteks-verteks data untai sudah terpilih Iterasi dihentikan, verteks V5 telah diberi tanda potensial. Jarak terpanjang dari verteks V1 ke verteks V5 $=11$ Lintasan terpanjang dicapai secara mundur (backward). Lintasan terpanjang dicapai secara mundur (backward).

- Besar potensial V5 - besar potensial V3 = jarak dari V3 ke V5 $(11-8=3)$. Benar Lintasan terpendek: -V3-V5

- Besar potensial V3 - besar potensial V2 = jarak dari V2 ke V3 $(8-5=3)$. Benar Lintasan terpendek: V2-V3-V5

- Besar potensial V2 - besar potensial V4 = jarak dari V4 ke V2 $(5-4=1)$. Benar Lintasan terpendek: V4-V2-V3-V5

- Besar potensial V4 - besar potensial V1 = jarak dari V1 ke V4 $(4-0=4)$. Benar Lintasan terpendek: V1-V4-V2-V3-V5

Pencarian lintasan dihentikan, lintasan terpanjang dari verteks V1 ke verteks V5 adalah V1-V4V2-V3-V5

\section{KESIMPULAN DAN SARAN}

Bedasar hasil analisis penelitian dan pengujian pada aplikasi ini dapat disimpulkan beberapa hal sebagai berikut:

- Pengembangan LPA berhasil mencari jalur terpanjang pada graf bersambung berarah beruntai.

- Aplikasi komputer pada pengembangan LPA berhasil mencari jalur terpanjang secara cepat dan tepat berbanding pencarian secara manual.

Pada penelitian ini masih banyak terdapat kekurangan yang perlu diteliti lebih lanjut sebagai bahan untuk pengembangan sistem. Beberapa saran yang dapat diberikan guna pengembangan penelitian selanjutnya:

- Penambahan arc dikembangkan dengan cara visual.

- Penambahan jumlah maksimum penginputan verteks yang diijinkan.

- Penambahan besar bobot arc yang diijinkan.

\section{DAFTAR PUSTAKA}

Buckley, Fred. 2002. A Friendly Introduction To Graph Theory. New Jersey: Pearson Education, Inc.

Even, Shimon. 1979. Graph Algorithms. United State of America : Computer Science Press.

Gross, Jonathan. 1998. Graph Theory and Its Applications. Florida: CRC Press.

Wilson, Robin J. 1990. Graphs: An Introductory Approach. Canada : John Wiley \& Sons. 